\title{
ALUMNI MENURUT PERSPEKTIF TOTAL QUALITY MANAGEMENT (TQM)
}

\author{
Kharisul Wathoni \\ IAIN Ponorogo \\ wathoni@iainponorogo.ac.id
}

\begin{abstract}
Alumni have a strategic role including improving the quality of education and developing various extracurricular activities in schools and alumni who have competence can play an important function in building public opinion to attract new students and public. This article discusses the role of alumni according to the Total Quality Management (TQM) perspective to find out related matters, namely the understanding and role of alumni, how the characteristics of integrated quality schools and how alumni management is according to the TQM perspective. The results of the analysis show the characteristics of quality schools have 5 quality pillars which include a focus on customers, total involvement, measurement, commitment and continuous improvement. The pillars are based on school beliefs. Alumni are able to make many contributions in improving the quality of education, therefore there is a need for alumni management. Alumni management includes the development of alumni networks, alumni construction of educational institutions, institutional governance of alumni management and methods for tracing alumni data through electronic and social media.
\end{abstract}

Keywords: Alumni, educational institutions, schools, total quality management.

Abstrak: Alumni memiliki peran strategis diantaranya peningkatan mutu pendidikan dan pengembangan berbagai kegiatan ekstrakurikuler yang produktif di sekolah dan alumni yang berprestasi dan memiliki kompetensi yang mumpuni dapat memainkan fungsi penting dalam membangun opini publik untuk menarik minat calon siswa baru. Artikel ini membahas peran alumni menurut prespektif Total Quality Management (TQM) untuk mengetahui hal-hal terkait, yaitu pengertian dan peran alumni, bagaimana karakteristik sekolah bermutu terpadu dan bagaimana manajemen alumni menurut prespektif TQM. Hasil analisis menunjukkan karakteristik sekolah bermutu memiliki 5 pilar mutu yang meliputi fokus pada kostumer, keterlibatan total, pengukuran, komitmen dan perbaikan berkelanjutan. Pilar-pilar tersebut didasarkan pada keyakinan sekolah. Alumni mampu memberikan banyak kontribusi dalam peningkatan mutu pendidikan, maka dari itu perlu adanya manajemen alumni. Manajemen alumni mencakup pengembangan jejaringan alumni, konstrubusi alumni terhadap lembaga pendidikan, tata kelola kelembagaan manajemen alumni dan metode penelusuran data alumni melalui media elektronik maupun sosial media.

Kata kunci: Alumni, lembaga pendidikan, sekolah, total quality management.

\section{PENDAHULUAN}

Pada era globalisasi, dunia bisnis termasuk di dalam dunia pendidikan dihadapkan kepada persaingan global. Para pelaku bisnis dengan mudah mempromosikan produk dan layanan mereka tanpa dibatasi ruang dan waktu, ${ }^{1}$ hal tersebut juga berpengaruh pada

\footnotetext{
${ }^{1}$ Marzuki Mahmud, Manajemen Mutu Perguruan Tinggi, (Jakarta: PT RajaGrafindo, 2012), hlm. 6.
} 
kehidupan bangsa. Kehidupan bangsa merupakan lingkungan pendidikan dan suprasistem dari sistem pendidikan yang bekerja bersama-sama dengan sistem lainnya (misalnya ekonomi, hukum, politik, sosial budaya, kesehatan, agama dan sebagainya) dalam mencapainya tujuan nasional. ${ }^{2}$

Pendidikan nasional merupakan tanggung jawab bersama dari berbagai pihak. Pendidikan yang bermutu akan terwujud karena adanya keterlibatan segenap komponen bangsa. Pendidikan yang bermutu akan berdampak pada layanan pendidikan yang adil dan merata bagi seluruh warga negara tanpa terkecuali, termasuk mereka yang membutuhkan pendidikan berkebutuhan khusus. Oleh karenanya, diperlukan manajemen mutu pendidikan yang dikonstruksi secara efektif dan efisien yang dapat menjawab persoalan-persoalan pendidikan dewasa ini. Manajemen mutu menjadi sebuah keniscayaan dalam memastikan penyelenggaraan proses pendidikan yang bermutu. Mutu pendidikan sebenarnya merupakan tanggung jawab bersama dari berbagai pihak dan memerlukan komitmen yang kuat dalam menjamin keterlaksanaan proses-proses pendidikan yang bermutu. ${ }^{3}$

Di dalam dunia pendidikan dikhotomi antara prioritas pada produktivitas (productivity) atau prioritas mutu (quality) dapat terjadi ketika di satu sisi menginginkan tingkat kelulusan yang tinggi, tapi di sisi lain juga menginginkan mutu lulusan sangat baik. Wilborn dan Cheng dalam Bujang Rahman menekankan bahwa dua hal tersebut, produktivitas dan mutu tidak bisa dipisahkan. ${ }^{4}$

Pembangunan pendidikan bukan hanya berfokus pada penyediaan faktor input pendidikan juga harus lebih memperhatikan faktor proses pendidikan. Input yang baik tidak otomatis menjadi jaminan terjadi peningkatan mutu. Bahkan selain input dan proses masih juga memperhatikan keberagaman peserta didik, kondisi lingkungan dan peran serta masyarakat (termasuk alumnus). ${ }^{5}$ Sehingga dari lulusan yang dihasilkan menjadi alumni yang bisa melanjutkan ke jenjang berikutnya pada sekolahan yang lebih bermutu dan dapat memenuhi kebutuhan pasar pada dunia kerja karena memiliki skill yang terampil. Alumni juga sebagai salah satu alat ukur perbaikan untuk peningkatan mutu pendidikan.

Artikel ini akan membahas lebih lanjut tentang alumni menurut prespektif Total Quality Management (TQM) untuk mengetahui hal-hal terkait, yaitu pengertian dan peran

${ }^{2}$ Syaiful Sagala, Manajemen Srategik dalam Peningkatan Mutu Pendidikan, Cet. Ke-6, (Bandung: Alfabeta, 2013), hlm.16.

${ }^{3}$ Bujang Rahman, Manajemen Mutu Lembaga Pendidikan Tenaga Kependidikan; Teori dan Praktik Produktivitas, Cet. Ke-1, (Yogyakarta: Graha Ilmu, 2013), hlm. 17-18.

${ }^{4}$ Ibid., hlm. 27.

${ }^{5}$ Eka Prihatin, Manajemen Peserta Didik, (Bandung: Alfabeta, 2012), hlm. 156. 
alumni, bagaimana karakteristik sekolah bermutu terpadu dan bagaimana manajemen alumni menurut prespektif TQM.

\section{PENGERTIAN DAN PERAN ALUMNI}

Arti kata "Alumni" di era modern ini menandai lulusan atau mantan mahasiswa dari Institut, Universitas dan sekolah tinggi. Alumni berasal dari bahasa latin yakni bentuk plural dari "Alumnus" artinya dalam bahasa jerman "Zoegling" atau diterjemahkan bebasnya seperti "ernaehren". Berarti kita masih merasa ada ikatan karena pernah di"suapi" oleh induk kita "almamater"(Uni dimana kita studi). ${ }^{6}$ Alumni menurut Kamus Besar Bahasa Indonesia (KBBI) adalah orang-orang yang telah mengikuti atau tamat dari suatu sekolah atau perguruan tinggi. Sedangkan alumnus menurut kamus yang sama mempunyai pengertian orang yang telah mengikuti atau tamat dari suatu sekolah atau perguruan tinggi. ${ }^{7}$

Dikatakan alumni, apabila sudah lulus dari lembaga pendidikan. Setelah lulus, secara formal hubungan peserta didik dengan lembaga pendidikan sudah selesei. Namun demikian, hubungan peserta didik dengan lembaga pendidikan dapat dilanjutkan melalui wadah ikatan alumni. Sekolah dapat memperoleh keuntungan dengan adanya hubungan alumni. Lembaga pendidikan atau sekolah dapat menjaring berbagai informasi dari alumni. ${ }^{8}$

Satu hal yang perlu disadari dan menjadi sebuah keniscayaan, semua siswa yang sukses menjalani masa pendidikan di sekolah pada akhirnya akan menjadi alumni. Artinya, salah satu indikator keberhasilan proses pendidikan dapat dilihat dari keberhasilan alumni dalam menjalankan peran mereka di jenjang pendidikan yang lebih tinggi maupun berbagai bidang pekerjaan yang mereka jalani secara profesional sesuai minat dan kemampuan. Berikut adalah peran strategis yang dimiliki alumni:

1. Peningkatan mutu pendidikan dan pengembangan berbagai kegiatan ekstrakurikuler yang produktif di sekolah, alumni dapat berperan sebagai katalis dengan memberikan berbagai masukan kritis dan membangun kepada almamater mereka.

2. Sesuai peran alaminya, alumni yang berprestasi dan memiliki kompetensi yang mumpuni dapat memainkan fungsi penting dalam membangun opini publik untuk menarik minat calon siswa baru. Alumni, disadari atau tidak, merupakan salah satu acuan utama yang mendasari keputusan para orang tua dan calon siswa dalam menentukan pilihan sekolah.

6 https://cahyodirjenddik.wordpress.com/2013/04/13/e-database-alumni-di-sma-sebagai-wujud-usahapengembangan-sekolah/. Diakses pada tanggal 20 Desember 2014.

7 Suharso dan Ana Retnoningsih, Kamus Besar Bahasa Indonesia Edisi Lux, cet. Ke-11, (Semarang: CV. Widya Karya, 2013), hlm. 31.

${ }^{8}$ Badrudin, Manajemen Peserta Didik, (Jakarta: PT Indeks, 2014), hlm. 69. 
3. Alumni, sebagai produk utama dari pabrik pendidikan bertajuk sekolah juga diharapkan mampu mengembangkan jaringan dan membangun pencitraan insitusi di luar. Penciptaan peluang usaha, kerja dan magang, kesempatan beasiswa, serta sirkulasi berbagai macam informasi penting seputar dunia pendidikan dan kerja merupakan beberapa contoh riil yang dapat dikontribusikan oleh alumni melalui jaringan yang dimiliki.

4. Secara internal sekolah, keberadaan alumni di berbagai bidang usaha, lapangan pekerjaan dan institusi pendidikan dapat memberikan gambaran dan inspirasi kepada para siswa/i, sehingga pada gilirannya dapat memotivasi mereka dalam menentukan prioritas dan citacita ke depan. ${ }^{9}$

Alumni sebagai salah satu petaruh atau steakholders sekolah tentu saja diharapkan memiliki peran dan memberikan konstribusi yang tidak kecil terhadap sekolah. Memang sekolah pada umunya sekarang ini membutuhkan bantuan finansial, tetapi sebenarnya bukan itu saja yang diharapkan tetapi juga menyangkut bantuan pengelolaan manajemen, peningkatan sumber daya termasuk personilnya, sistem kepemimpinan dan organisasi, komunikasi dan kerjasama,dan sebagainya. Singkatnya dari berbagai segi, alumnus dapat memberikan sumbangsih. ${ }^{10}$

Hubungan antara sekolah dengan para alumni dapat dipelihara lewat pertemuanpertemuan yang diselenggarakan oleh para alumni, yang biasa disebut "reuni". Prestasi yang dicapai para alumni dari lembaga pendidikan (sekolah) ini perlu didata atau dicatat oleh lembaga. Sebab catatan tersebut sangat berguna bagi lembaga dalam mempromosikan lembaga pendidikannya. ${ }^{11}$

Kerjasama dan sinergi yang harmonis antara alumni dengan sekolah, siswa, dan orang tua siswa akan memiliki dampak yang besar bagi pengembangan sekolah secara berkesinambungan di masa mendatang.

\section{KARAKTERISTIK SEKOLAH BERMUTU TERPADU}

Dewasa ini semua lembaga pendidikan berorientasi pada mutu. Lembaga pendidikan dikatakan "bermutu" jika input, proses dan hasilnya dapat memenuhi persyaratan yang dituntut oleh jasa pengguna jasa pendidikan. Bila performance-nya dapat melebihi persyaratan yang dituntut oleh stakeholder (user), maka suatu lembaga pendidikan baru bisa

${ }^{9}$ Ibid.

${ }^{10}$ Eka Prihatin, Manajemen ..., hlm. 155.

11 Tim Dosen Administrasi Pendidikan Universitas Pendidikan Indonesia, Manajemen Pendidikan, (Bandung: Alfabeta, 2014), hlm. 214. 
dikatakan unggul. ${ }^{12}$ Sehingga sebelum mengetahui hasil pendidikan atau bisa disebut lulusan yang nantinya menjadi alumni, maka akan dibahas tentang karakteristik sekolah bermutu terpadu, yang mana sekolah tersebut sebagai tempat untuk memproses hasil pendidikan tersebut.

Pada dasarnya, sekolah bermutu memiliki 5 karakteristik, yang diidentifikasi seperti pilar mutu yang meliputi fokus pada kostumer, keterlibatan total, pengukuran, komitmen dan perbaikan berkelanjutan. Pilar-pilar tersebut didasarkan pada keyakinan sekolah seperti kepercayaan, kerja sama dan kepemimpinan. Mutu dalam pendidikan meminta adanya komitmen untuk menciptakan sebuah lingkungan yang memungkinkan para staf dan siswa menjalankan pekerjaan sebaik-baiknya. Pilar-pilar tersebut digambarkan sebagai berikut: ${ }^{13}$

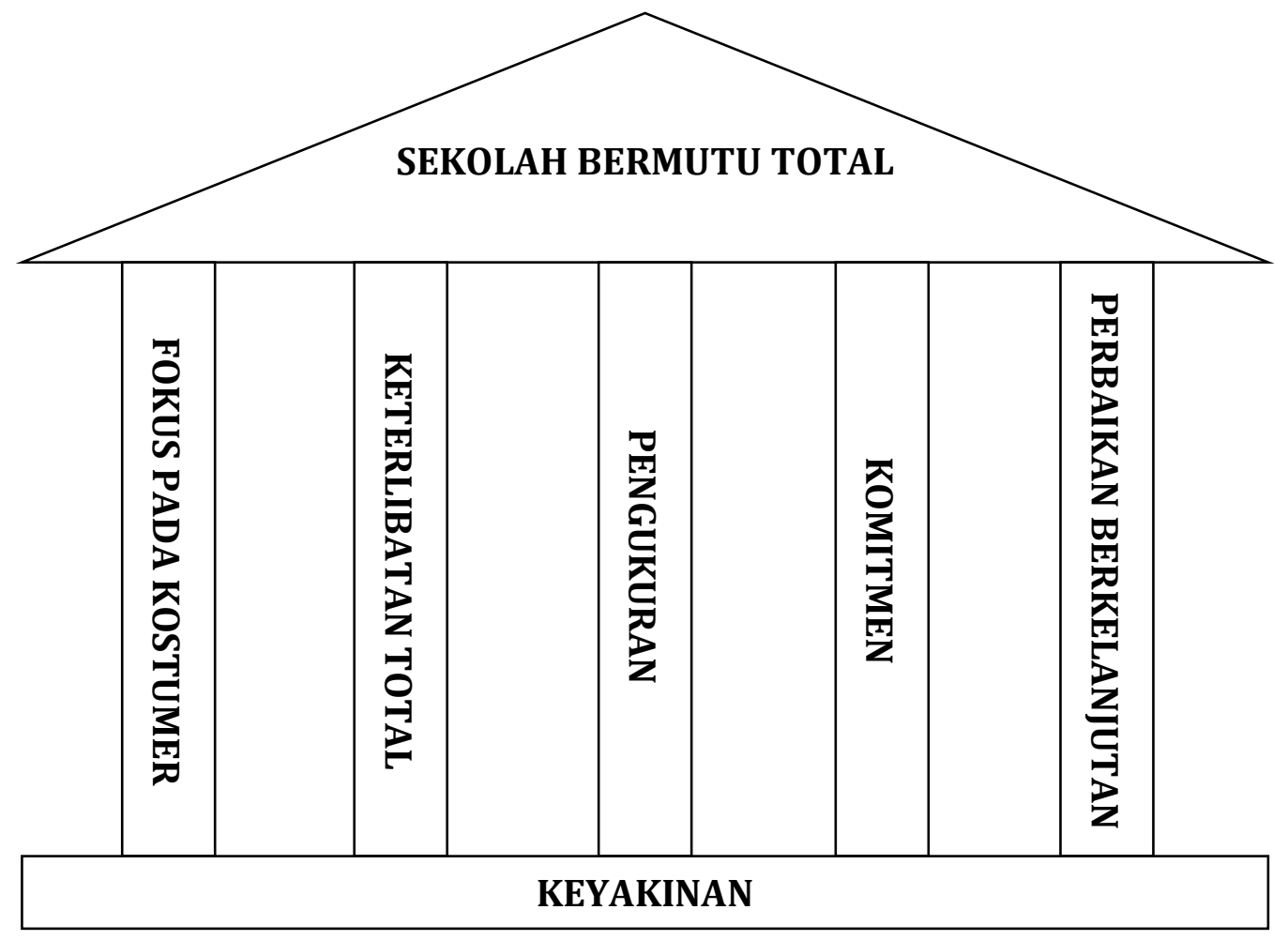

Gambar 1. Karakteristik Sekolah Bermutu Terpadu

Penjelasan dari gambar tersebut, sebagai berikut:

1. Fokus pada kostumer

Dalam sekolah bermutu terpadu, setiap orang menjadi kostumer dan pemasok sekaligus.

Sekolah memiliki kostumer internal dan eksternal. Kostumer internal adalah orang tua,

${ }^{12}$ Mujamil Qomar, Manajemen Pendidikan Islam, (Jakarta: Erlangga, 2007), hlm. 206.

13 Jerome S. Arcaro, Pendidikan Berbasis Mutu, Terj. Yosal Iriantara, Cet. Ke-IV, (Yogyakarta: Pustaka Pelajar, 2007), hlm. 38. 
siswa, guru, administrator, staf dan dewan sekolah yang berada di dalam sitempendidikan. Kostumer eksternal adalah masyarakat, perusahaan, keluarga, militer dan pergurun tinggi yang berada di luar organisasi, namun memanfaatkan output proses pendidikan

2. Keterlibatan total

Setiap orang harus berpartisipasi dalam transformasi mutu. Mutu bukan hanya tanggung jawab dewan sekolah atau pengawas. Mutu merupakan tanggung jawab semua pihak. Mutu menuntut setiap orang memberi kostribusi.

\section{Pengukuran}

Sekolah tidak dapat memenuhi standar mutu yang ditetapkan masyarakat, sekalipun ada sarana untuk mengukur kemajuan berdasarkan pencapaian standar tersebut. Jadi, para siswa menggunakan nilai ujian untuk mengukur kemajuannya di kelas. Komunitas menggunakan anggaran sekolah untuk mengukur efisiensi proses sekolah.

4. Komitmen

Para pengawas sekolah dan dewan sekolah harus memiliki komitmen pada mutu. Bila mereka tidak memiliki komimen, proses transformasi mutu tidak akan dapat dimulai karena kalaupun dijalankan pasti gagal. Setiap orang perlu mendukung upaya mutu.

5. Perbaikan berkelanjutan

Para profesioanl pendidikan harus secara konstan menemukan cara untuk menangani masalah yang muncul, mereka harus memperbaiki proses yang dikembangkannya dan membuat perbaikan yang diperlukan. ${ }^{14}$

Sekolah bermutu total atau terpadu tersebut, memiliki pilar-pilar yang kuat yang didasarkan pada keyakinan, yang mana apabila pada salah satu pilar tidak ada atau tidak kuat maka ada kemungkinan sekolahan tersebut akan tidak akan menyangga atau bahkan menjadi roboh, sehingga untuk menciptakan sekolah yang bermutu total perlu kelima pilar tersebut, yang nantinya dapat mengahsilkan produk (alumni) yang bermutu yang diharapkan sesuai tujuan pendidikan.

\section{ALUMNI MENURUT PRESPEKTIF TOTAL QUALITY MANAGEMENT (TQM)}

Sebenarnya mutu pendidikan menjadi sebuah problem internasional. Hampir semua negara berkembang di dunia ini menghadapi persoalan mutu pendidikan, sehingga pemerintah, praktisi dan pemikir pendidikan berusaha keras keluar dari krisis mutu pendidikan tersebut. Dalam konteks Indonesia, mutu pendidikan baru pada tingkat istilah

\footnotetext{
${ }^{14}$ Ibid., hlm. 38-42
} 
yang mudah diucapkan dan diharapkan oleh berbagai kalangan. Berbagai survei pada level internasional masaih menempatkan mutu pendidikan di Indonesia pada rangking bawah (berkisar pada rangking ke-116). Pada tingkat Asia Tenggara, mutu pendidikan di Indonesia menempati urutan paling bawah. ${ }^{15}$

Manajemen mutu yang lebih populer dengan istilah TQM adalah suatu cara meningkatkan kerja performansi secara terus menerus dalam setiap tingkatan operasi atau proses dalam setiap area fungsional dari suatu organisasi dengan menggunakan semua sumber daya manusia dan modal yang tersedia. Sementara Ross dalam Wiliam Mantja yang dikutip oleh Marno dan Triyo Supriyatno mendefinisikan TQM sebagai integrasi dari semua fungsi dan proses dalam organisasi untuk memperoleh dan mencapai perbaikan serta peningkatan kualitas barang sebagai produk dan layanan yang berkesinambungan. Tujuan utamanya adalah kepuasan konsumen atau pelanggan. ${ }^{16}$

TQM dapat membantu institusi untuk mengelola perubahan-perubahan yang terjadi dan menetapkan agenda mereka sendiri untuk menyesuaikan diri dengan tekanan dari luar institusi atau organisasi mereka. Meskipun demikian, TQM tidak akan dapat memberikan hasil yang instan, dan belum tentu juga akan dapat memberikan hasil terbaik bagi institusi pendidikan. TQM hendaknya dipandang sebagai seperangkat cara atau alat yang dapat diterapkan dalam manajemen sebuah institusi pendidikan, termasuk di Indonesia. Dengan demikian, institusi pendidikan akan dikelola dengan manajemen yang lebih baik, sehingga hasil keluarannya (alumni) akan lebih berkualitas.

Peningkatan mutu sekolah dengan manajemen yang efektif, efisien dan produktif dalam mencapai sasaran tujuan pendidikan dengan mendasarkan pada pengelolaan kurikulum ditujukan untuk menciptakan lulusan (output) yang kompeten dalam membangun kehidupan diri sendiri, masyarakat, bangsa dan negaranya yang ditandai dengan perwujudan kebiasaan berfikir dan bertindak siswa dalam kehidupan sehari-hari, baik di keluarga, sekolah dan masyarakat. ${ }^{17}$

Pelajar atau peserta didik seringkali dianggap sebagai produk dari pendidikan. Dalam pendidikan sering mengatakan seolah-olah pelajar adalah hasil dari pendidikan, khususnya merujuk pada penerapan disiplin dan cara bersikap di institusi-institusi tertentu. Pendidikan

\footnotetext{
15 Mujamil Qomar, Kesadaran Pendidikan: Sebuah Penentu Keberhasilan Pendidikan, Cet. Ke-1, (Yogyakarta: Ar-Ruzz Media, 2012), hlm. 41-42.

16 Marno dan Triyo Supriyatno, Manajemen dan Kepemimpinan Pendidikan Islam, Cet. Ke-2, (Bandung: PT Refika Aditama, 2013), hlm.110.

${ }^{17}$ Aminatul Zahroh, Total Quality Management: Teori dan Praktik Manajemen untuk Mendongkrak Mutu Pendidikan, (Yogyakarta: Ar-Ruzz Media, 2014), hlm. 154.
} 
seolah-olah merupakan sebuah jalur produksi. Produk adalah sebuah subyek dari proses jaminan mutu, maka yang harus dilakukan produsen adalah:

1. Menentukan dan mengontrol sumber persediaan.

2. 'Bahan mentah' harus melewati sebuah atau beberapa proses standar yang telah diterapkan.

3. Hasil produksi harus dapat memenuhi spesifikasi yang ditetapkan dan didefinisikan sebelumnya. ${ }^{18}$

Model semacam itu tidak mudah diterapkan dalam pendidikan. Pendidikan dilihat sebagai sebuah jasa atau layanan dan bukan sebuah bentuk produksi. Perbedaan antara produk dan jasa sangat penting, sebab ada perbedaan fundamental antara keduanya yang akan melahirkan tentang bagaimana mutu keduanya dapat dijamin. ${ }^{19}$

Menurut Ann komariah dan Cepi Tiratna dalam Mukhammad Ilyasin dan Nanik Nurhayati, bahwa jasa/pelayanan atau produk tersebut dikatakan bermutu apabila minimal menyamai bahkan melebihi harapan pelanggan. Dengan demikian, mutu suatu jasa maupun barang selalu berorientasi pada kepuasan pelanggan. Apabila kata mutu digabungkan dengan kata pendidikan, berarti menunjuk kepada kualitas produk yang dihasilkan lembaga pendidikan atau sekolah. Yaitu dapat diidentifikasi dari banyaknya siswa yang memiliki prestasi, baik prestasi akademik maupun yang lain, serta lulusannya relevan dengan tujuan. Mutu pendidikan dapat dilihat dalam dua hal, yakni mengacu pada proses pendidikan dan hasil pendidikan. Proses pendidikan yang bermutu apabila komponen pendidikan terlibat dalam proses pendidikan itu sendiri. Faktor-faktor dalam proses pendidikan adalah berbagai input, seperti bahan ajar, metodologi, saran sekolah, dukungan administrasi dan sarana prasarana dan sumber daya lainnya sera penciptaan suasana kondusif. Sedangkan mutu pendidikan dalam konteks hasil pendidikan mengacu pada prestasi yang dicapai oleh sekolah pada setiap kurun waktu tertentu. ${ }^{20}$

Produk pendidikan atau pendidikan tersebut yang nantinya menjadi alumni dari lembaga pendidikan yang telah memprosesnya menjadi produk-produk yang bermutu sesuai yang dibutuhkan di pasaran, dan juga sebagai pemasar dari lembaga pendidikan yang telah mendidiknya.

${ }^{18}$ Edward Sallis, Total Quality Management in Education, Terj. Ahmad Ali Riyadi dan Fahrurrozi, Cet. Ke- XVI, (Yogyakarta: IRCiSoD, 2012), hlm.61.

${ }^{19}$ Ibid., hlm. 62.

${ }^{20}$ Mukhamad Ilyasin dan Nanik Nurhayati, Manajemen Pendidikan Islam: Konstruksi Teoretisdan Praktis, Cet. Ke-1, (Malang: Aditya Madia Publishing, 2012), hlm. 292. 
Dalam kaitannya dengan implementasi TQM di Perguruan Tinggi jika dilihat dari mutu dan produktivitas, maka pruduk utama adalah lulusan. Imdikator lulusan dapat dilihat dari indeks prestasi kumulatif (IPK) lulusannya. Di sisi lain, produktivitas diindentikkan dengan masa mukim atau lama waktu studi mahasiswa. Dengan demikian, kinerja lembaga pendidikan yang paling baik adalah ketika mereka mampu menghasilkan lulusan yang tepat waktu dan memiliki IPK yang tinggi. Sebaliknya kinerja akan rendah jika masa mukim mahasiswanya lamadan IPKnya rendah. ${ }^{21}$

Sedangkan dalam konteks pendidikan Islam, pengarahan bakat, minat serta kemampuan siswa dan penyaluran para alumni untuk memasuki lapangan kerja merupakan bentuk kepedulian lembaga pendidikan Islam terhadap siswa/mahasiswa maupun alumninya. Bila kepedulian ini benar-benar dapat diwujudkan dengan baik dan dapat merasakan kemudahan, terutama dalam mendapatkan lapangan pekerjaan, tentu dapat meningkatkan posisi tawar lembaga pendidikan Islam tersebut di masyarakat secara luas. Sekarang ini, rumus yang dipegang siswa/mahasiswa sangat pragmatis. Siapa pun yang menjadi manajer dan apa pun nama lembaga pendidikannya, selama pihak lembaga pendidikan dapat mempromosikan para alumninya, maka lembaga tersebut akan mereka serbu. ${ }^{22}$ Maka dari itu, peran alumni juga memberikan dampak yang positif terhadap lembaga pendidikannya dalam meningkatkan mutu pendidikan.

Implementasi TQM pada lembaga pendidikan perlu dilakukan dengan serius mengingat hal ini akan berimplikasi pada program-program bermutu baik akademik maupun non akademik agar dapat memenuhi standar pelayanan pada pelanggan. Sasaran implementasi TQM pada lembaga pendidikan adalah kualitas pelayanan yang dapat memberikan kepuasan kepada pelanggan terutama yang terkait dengan pelayanan pendidikan dan pembelajaran. ${ }^{23}$ Pelanggan yang utama adalah siswa dan keluarganya yang nantinya menjadi lulusan (alumni) yang sesuai yang diharapkan.

\section{MANAJEMEN ALUMNI MENURUT PRESPEKTIF TQM}

Alumni dari lembaga pendidikan, secara administrasi sudah lepas dalam manejemen sekolah, namun dengan adanya alumni memberikan manfaat, salah satunya adalah akan meningkatkan mutu lembaga pendidikannya dan sebagai bentuk evaluasi untuk perbaikan sekolah menjadi lebih baik lagi. Tentunya alumni harus tetap dijaga, karena sudah

\footnotetext{
${ }^{21}$ Bujang Rahman, Manajemen..., hlm. 29.

${ }^{22}$ Mujamil Qomar, Manajemen..., hlm. 148.149.

${ }^{23}$ Bujang Rahman, Manajemen..., hlm. 29-30.
} 
memberikan kostribusi untuk lembaga pendidikan, sehingga untuk mengelolanya perlu adanya manajemen alumni agar alumni tetap terjaga dan menjaga nama baik sekolahnya. Namun itu tidak mudah dalam penerapan manajemennya, kelemahan manajemen menjadi landasan yang mendasari adanya perbaikan terus menerus pada implemantasi TQM dalam pendidikan, sehingga dapat diinventarisir beberapa penyakit manjemen, sebagai berikut:

1. Kurang konsisten dalamperumusan tujuan, yakni sering bergantinya tujuan institusi.

2. Seringnya berpikir jangka pendek yang terkait dengan penyakit pertama.

3. Evaluasi personal yang selalu didasarkan pada rating evaluasi tahuanan.

4. Penggunaan gambaran visual untuk mengukur sebuah keberhasilan. ${ }^{24}$

Berdasarkan uraian tersebut, maka sangat penting dalam menerapkan TQM dalam pendidikan dan juga bisa dipakai untuk menerapkan dalam manajemen alumni. Manajemen alumni menurut prespektif TQM ini akan diambilkan salah satu contoh, yaitu manajemen alumni di Universitas Islam Indonesia Yogyakarta, berikut penjelasannya:

\section{Ruang lingkup manajemen alumni}

a. Pengembangan Jejaring Alumni

1) Konsep pengembangan jejaring berbasis alumni

- Mengaktifkan jejaring yang ada

- Mengembangkan jejaring melalui media yang multi channel

- Mengefektifkan jejaring dengan mengkristalkan melalui kerjasama yang saling menguntungkan

2) Membuka peluang jejaring kerjasama antara UII dengan alumni, alumni dengan alumni, alumni - UII - pengguna lulusan (masyarakat). Peluang ini dapat berupa: penelitian, peluang lowongan pekerjaan, beasiswa, penawaran lulusan, pemagangan, promosi, event information, professional directory (senarai profesional/ahli yang dimiliki oleh alumni kepada masyarakat luas)

3) Bentuk jejaring

- Jejaring formal dalam IKA

- Jejaring informal

- Mengembangkan jejaring sosial networking berbasis web (facebook, friendster, flicker dll)

b. Kontribusi Alumni kepada Universitas

1) Pendanaan (sebagai subject fund raising

${ }^{24}$ S. Shoimatul Ulfa, Buku Pintar Teori-teori Manajemen Pendidikan Efektif, (Yogyakarta: Berlian, 2013), hlm. 43-44. 
2) Beasiswa kepada mahasiswa (scholarship)

3) Peluang informasi dan tempat kerja magang kepada mahasiswa

4) Rekrutasi staf UII

c. Pengembangan Kurikulum

1) Pemutakhiran kurikulum berbasis relevansi dengan kebutuhan pasar / dunia kerja

2) Continuing Education: Universitas dapat dikembangkan menjadi media belajar sepanjang hayat bagi alumni

3) Mengembangkan Customer Satisfaction Index: BPM

4) Pemanfaatan alumni sebagai dosen tamu, dosen profesional, seminar, training dll. baik dalam akademik maupun bidang pragmatis (manajerial dll)

\section{Kelembagaan Manajemen Alumni}

a. Tata Kelola Kelembagaan Manajemen Alumni di Universitas

Pada tingkat universitas, fungsi koordinasi umum dan kebijakan mengenai manajemen alumni di bawah kendali Wakil Rektor III. Beberapa lembaga di UII yang memberikan dukungan dalam manajemen alumni, yaitu:

1) Direktorat Pemasaran, Kerjasama dan Alumni (DPKA), memiliki wewenang dalam:

- Koordinasi di tingkat Universitas

- Memastikan unit di Fakultas menjalankan tugas penelusuran data alumni

- Membuat media komunikasi yang dapat diakses alumni (kerjasama dengan UIInews dan Humas yang berbasis hardcopy yang disebarkan ke alumni)

- Membuat media komunikasi berbasis web (terkait dengan sistem informasi)

2) Fakultas, memiliki wewenang dalam:

- Koordinasi di tingkat fakultas

- Memastikan adanya pembaruan master data dengan melakukan eksekusi penelusuran data umum alumi

- Menyediakan sumberdaya (manusia, anggaran, ruang dan perangkat kebijakan) untuk suksesnya penelusuran data tersebut. Sumber daya ini diharapkan dapat membantu Program Studi dalam melakukan penelusuran spesifik.

3) Program Studi, memiliki wewenang dalam:

- Melakukan eksekusi penelusuran data umum alumi khusus untuk kebutuhan Prodi terutama yang berkaitan dengan akademik dan pemutakhiran kurikulum. 
- Membantu Fakultas mensukseskan penelusuran data alumni.

4) Unit Layanan Alumni. Alumni Career Center, kelembagaan ini diharapkan menjadi ujung tombak pelayanan terhadap alumni. ACC juga dibebani fungsi untuk penelusuran data alumni bekerjasama dengan Fakultas.

b. Ikatan Keluarga Alumni

Merupakan partner bagi UII baik di paras universitas, fakultas maupun program studi untuk memperkuat manajemen alumni.

\section{Teknologi Informasi}

a. Pengembangan sistem

Sistem informasi alumni harus menawarkan solusi yang lengkap meliputi kebutuhan jejaring profesional dan sosial untuk alumni. Secara garis besar sistem ini diharapkan berisi paling tidak: Customer Account Management, Customizable Functionality, Data Import/Export, Event Management, Jobs Board, Mail Merge, Member Forums, Member Profile \& Account Access, Member Search Functions, Online Event Registration, Online Member Interface, Onsite Registration, Reporting, Secure Member Directory.

Sistem yang berbasis web ini harus memenuhi beberapa criteria, diantaranya: memungkinkan alumni untuk memperharui data, informasi dan kontak dengan mudah, memungkinkan alumni mendapatkan informasi kegiatan atau hal yang dibutuhkan dengan mudah. Sangat dimungkinkan :bila dapat dibuat "customizable" dengan seperti konsep "My Account", memungkinka adanya "personal web" untuk alumni (saat ini sedang dikembangkan portal blog yang bisa dipakai oleh alumni pula, adanya newsletter sign-up, kemudahan administrasi untuk membuat berita dan publikasi event, menampilkan "spotlight alumni" untuk menunjukkan cerita sukses.

b. Kemampuan Analisis Berbasis Teknologi Informasi

Setelah diperoleh cukup banyak data alumni, data tersebut dapat digunakan untuk keperluan lebih lanjut. Bahkan dengan analisis dan pemaknaan tersebut, mampu memaksimalkan daya guna data tersebut dalam kaitannya untuk proses pengambilan keputusan. Pemaknaan data yang cukup besar tersebut membutuhkan metode dan teknologi yang handal. Oleh karena itu, sarana Information Technology (IT) yang dikembangkan harus dilengkapi dengan fitur untuk keperluan tersebut. Business Intelligence (BI) merupakan salah satu proses yang dapat disertakan sebagai salah satu fitur penting dalam sistem informasi yang akan dikembangkan. BI 
merupakan aplikasi dan teknologi untuk mengumpulkan, menyimpan, menganalisis dan menyediakan akses ke data untuk membantu penggunanya dalam mengambil keputusan bisnis dengan lebih baik. Salah satu manfaat yang bisa diperoleh adalah UII (pihak terkait, dalam hal ini prodi, fakultas, maupun unuversitas) mampu melihat adanya kelemahan atau kekurangan selama proses akademis sekaligus dengan penyebabnya sebelum hal tersebut berkembang menjadi masalah yang serius. Beberapa fitur yang bisa diberikan, antara lain:

1) Querying, menyediakan informasi alumni berdasarkan kondisi tertentu, antara lain:

- Alumni yang memiliki pekerjaan dengan bidang yang sesuai.

- Alumni dengan masa tunggu mendapatkan pekerjaan yang cukup singkat.

- Alumni dengan gaji pertama yang cukup tinggi, dll.

2) Reporting, menyediakan pelaporan terhadap segala informasi alumni dalam batasan tertentu, seperti periodisasai (semester atau tahunan) dan program studi atau fakultas.

3) OnLine Analytical Processing (OLAP) dan statistical analysis, yang akan menyediakan analisis statistik sesuai dengan kebutuhan.

Untuk keperluan tersebut, perlu sistem yang dibuat harus memiliki kemampuan dalam mendukung proses pembuatan laporan dapat dilakukan dengan cepat, adanya Graphic User Interface (GUI) yang dapat dibentuk sesuai selera. mampu meminimalisasi masalah-masalah teknis, terutama terkait dengan human error, mudah dalam integrasi data, adanya konsolidasi informasi, karena data diolah dalam satu platform.

c. Pengembangan Infrastruktur

Seiring dengan bertambahnya jumlah alumni UII, maka perlu kiranya untuk senantiasa meningkatkan kualitas dan kuantitas layanan teknologi informasi.

\section{Metode Penelusuran Data Alumni}

Penggunaan media seperti SMS-Alumni, Email, Mailing List, Chatting atau Message Board, Temu Alumni, Telephone, Surat, Legalisir, dan Prasyarat Wisuda. Sedangkan dalam pelaksanaannya berada di tingkat Universitas: Staf khusus di bawah DPKA, tingkat Fakultas: Staf khusus di bawah Dekan dan tingkat Prodi: Staf Edukatif dan Administratif sebagai Unit Pelaksana.

5. Media Komunikasi dengan Alumni 
Pertemuan dapat dilakukan dengan cara mendorong penyelenggaraan Alumni Gathering atau temu Alumni baik di tingkat Universitas, Fakultas maupun Prod; mendorong penyelenggaraan Alumni Scientific Meeting; menghadirkan Alumni dalam Acara Sambutan Wisuda, maupun kegiatan ilmiah, training, seminar dan acara di Universitas, fakultas maupun prodi. Penyelenggaranya adalah: fakultas/prodi per angkatan, pertemuan IKA daerah dan pertemuan IKA pusat.

Media publikasi yang digunakan dapat berupa Bulletin / Newsletter online dan hardcopy dan memelihara komunikasi dengan multichannel (mailing list, social web dan lain-lain) serta mendorong pembentukan IKA cabang baru

6. Pengembangan Layanan Melalui Alumni Career Center

Menggunakan Job Seeker Workshop, Entrepreneur Workshop, Psikotes, InCampus Recruitment, Career Meeting, Job Fair, Internship, dan mengoptimalkan website ACC.

7. Sistem Perencanaan Pengembangan Pribadi (Personal Development Planning System PDPS)

PDPS merupakan suatu proses pendukung pembelajaran terstruktur yang dikembangkan institusi, dilaksanakan dan menjadi tanggung jawab para mahasiswa secara individual untuk merefleksikan berbagai pengalaman belajar, performansi, dan atau prestasi dan untuk merencanakan pengembangan personal, pendidikan, dan pengembangan karir individu mereka.

PDPS yang efektif membantu para mahasiswa untuk membuat link dan mendapatkan sebuah pandangan yang holistik tentang studi mereka dalam sebuah lingkungan modular. Merefeleksikan secara kritis, menjadi lebih independen, mengadopsi sebuah pendekatan yang lebih proaktif dalam studi, pencarian ekstrakurikuler, dan perencanaan karir. Memperkaya belajar mereka dalam satu konteks yang bervariasi. Membantu mereka merefleksikan dan menyadari apa yang sedang dan mengapa mereka sedang mempelajarinya, mendorong mereka untuk merencanakan ke depan dan menghubungan apa-apa yang telah mereka pelajari dengan dunia yang lebih luas.

PDPS yang efektif secara institusional juga memberikan keuntungan seperti para dosen memberikan nilai tambah terhadap pengalaman belajar mengajar, membantu para mahasiswa untuk mengambil tanggung jawab yang lebih besar atas belajar mereka sendiri, memfasilitasi monitoring kemajuan mahasiswa lebih efektif, memungkinkan para tutor menyediakan dukungan dan bimbingan akademik secara lebih fokus dan 
efektif. PDPS meningkatkan kapasitas dosen/tutor untuk menunjukkan kualitas dukungan yang sedang mereka berikan kepada para mahasiswa, menyediakan sebuah alat bukti tingkat pencapaian belajar mahasiswa secara individual sesuai dengan tujuan pembelajaran yang ditetapkan, dan ketika diaplikasikan, membantu meningkatkan efektivitas belajar berbasis kerja atau belajar terkait kerja.

Sistem ini memungkinkan alumni memberikan umpan balik secara langsung (on line) kepada institusi guna melakukan perbaikan-perbaikan secara kontinyu dan sistemik, sehingga employability lulusan UII menjadi lebih tinggi. ${ }^{25}$

\section{KESIMPULAN}

Alumni adalah orang yang telah mengikuti atau tamat dari suatu sekolah atau perguruan tinggi. Dan peran strategis yang dimiliki alumni adalah: peningkatan mutu pendidikan dan pengembangan berbagai kegiatan ekstrakurikuler yang produktif di sekolah, alumni yang berprestasi dan memiliki kompetensi yang mumpuni dapat memainkan fungsi penting dalam membangun opini publik untuk menarik minat calon siswa baru, alumni, sebagai produk utama dari pabrik pendidikan bertajuk sekolah juga diharapkan mampu mengembangkan jaringan dan membangun pencitraan insitusi di luar dan keberadaan alumni di berbagai bidang usaha, lapangan pekerjaan dan institusi pendidikan dapat memberikan gambaran dan inspirasi kepada para siswa/i.

Karakteristik sekolah bermutu memiliki 5 pilar mutu yang meliputi fokus pada kostumer, keterlibatan total, pengukuran, komitmen dan perbaikan berkelanjutan. Pilar-pilar tersebut didasarkan pada keyakinan sekolah.

Produk utama dalam TQM adalah lulusan atau alumni yang bermutu. Alumni yang memberikan banyak sumbangsih untuk meningkatkan mutu pendidikan, karena dengan hasil lulusan yang bermutu maka akan terbentuk kepercayaan pelanggan dan memberikan konstribusi kepada lembaga pendidikan.

Dari hasil lulusan yang disebut Alumni, tentunya akan memberikan banyak kontribusi dalam peningkatan mutu pendidikan, maka dari itu perlu adanya manajemen alumni. Manajemen alumni mencakup pengembangan jejaringan alumni, konstrubusi alumni terhadap lembaga pendidikan, tata kelola kelembagaan manajemen alumni dan metode penelusuran data alumni melalui media elektronik maupun sosial media.

${ }^{25}$ Dokumen Blue Print Manajemen Alumni Universitas Islam Indonesia Yogyakarta, (Yogyakarta: t.p, 2009), hlm. 1- 9. 


\section{DAFTAR PUSTAKA}

Arcaro, Jerome S. Pendidikan Berbasis Mutu, Terj. Yosal Iriantara, Cet. Ke-IV, (Yogyakarta: Pustaka Pelajar, 2007.

Badrudin. Manajemen Peserta Didik. Jakarta: PT Indeks, 2014.

Dokumen Blue Print Manajemen Alumni Universitas Islam Indonesia Yogyakarta. Yogyakarta: t.p, 2009.

https://cahyodirjenddik.wordpress.com/2013/04/13/e-database-alumni-di-sma-sebagai-wujudusaha-pengembangan-sekolah/. Diakses pada tanggal 20 Desember 2014.

Ilyasin, Mukhamad dan Nanik Nurhayati, Manajemen Pendidikan Islam: Konstruksi Teoretisdan Praktis, Cet. Ke-1, Malang: Aditya Madia Publishing, 2012.

Mahmud, Marzuki, Manajemen Mutu Perguruan Tinggi, Jakarta: PT RajaGrafindo, 2012.

Marno dan Triyo Supriyatno, Manajemen dan Kepemimpinan Pendidikan Islam, Cet. Ke-2, Bandung: PT Refika Aditama, 2013.

Prihatin, Eka. Manajemen Peserta Didik. Bandung: Alfabeta, 2012.

Qomar, Mujamil. Manajemen Pendidikan Islam, Jakarta: Erlangga, 2007.

, Kesadaran Pendidikan: Sebuah Penentu Keberhasilan Pendidikan, Cet. Ke-1, Yogyakarta: Ar-Ruzz Media, 2012.

Rahman, Bujang. Manajemen Mutu Lembaga Pendidikan Tenaga Kependidikan; Teori dan Praktik Produktivitas, Cet. Ke-1, Yogyakarta: Graha Ilmu, 2013.

Sagala, Syaiful. Manajemen Srategik dalam Peningkatan Mutu Pendidikan, Cet. Ke-6, Bandung: Alfabeta, 2013.

Sallis, Edward. Total Quality Management in Education, Terj. Ahmad Ali Riyadi dan Fahrurrozi, Cet. Ke- XVI, (Yogyakarta: IRCiSoD, 2012.

Suharso dan Ana Retnoningsih. Kamus Besar Bahasa Indonesia Edisi Lux. cet. Ke-11. Semarang: CV. Widya Karya, 2013.

Tim Dosen Administrasi Pendidikan Universitas Pendidikan Indonesia. Manajemen Pendidikan. Bandung: Alfabeta, 2014.

Ulfa, S. Shoimatul. Buku Pintar Teori-teori Manajemen Pendidikan Efektif. Yogyakarta: Berlian, 2013.

Zahroh, Aminatul. Total Quality Management: Teori dan Praktik Manajemen untuk Mendongkrak Mutu Pendidikan. Yogyakarta: Ar-Ruzz Media, 2014. 